\title{
GENDER-BASED ANALYSIS OF STUDENTS' ABILITY IN ANSWERING FACTUAL AND VOCABULARY-IN-CONTEXT QUESTIONS OF THE TOEFL-LIKE READING COMPREHENSION TEST
}

\author{
Cahya Destiyanti ${ }^{1}$, Muhammad Amin ${ }^{2}$, Lalu Jaswadi Putera ${ }^{3}$ \\ University of Mataram \\ lalujaswadi1981@gmail.com
}

\begin{abstract}
This study was aimed to find out whether or not there was a significant difference between male and female students' ability in answering factual and vocabulary-in-context questions of the TOEFL-Like reading comprehension test. Secondary data analysis was utilized by taking reading comprehension test scores of twenty-one male and twenty-one female students of the English Education Program. Samples were selected using random sampling technique. Data were analyzed using independent sample t-test. Results showed that the t-values of sig. 2-tailed was higher than 0.05 in male and female students' ability in answering both the factual questions $(0.267>0.05)$ and the vocabulary-in-context questions $(0.837>0.05)$. The results revealed that there was no significant difference between male and female students' ability in answering factual and vocabulary-in-context questions of the TOEFL-Like reading comprehension test.
\end{abstract}

Keywords: Reading Comprehension, Factual Question, Vocabulary-In Context Question, Gender, TOEFL

\begin{abstract}
Abstrak : Penelitian ini bertujuan untuk mengetahui apakah ada perbedaan yang signifikan antara kemampuan mahasiswa perempuan dan laki-laki dalam menjawab soal-soal berbentuk factual questions dan vocabulary-in-context questions pada tes kemampuan membaca TOEFL-like. Analisis data pada penelitian deskriptif kuantitatif ini menggunakan analisis data sekunder dengan mengambil data berupa skor tes kemampuan membaca TOEFL-like dari 21 peserta wanita dan 21 peserta laki-laki pada Program Studi Pendidikan Bahasa Inggris di Uiversitas Mataram yang dipilih menggunakan teknik random sampling. Analisis data menggunakan independent sample t-test SPSS. Hasil penelitian menunjukkan bahwa nilai tvalue dari sig. 2 -tailed lebih besar dari 0.05 yakni $0.267>0.05$ dalam kemampuan menjawab soal-soal factual questions dan $0.837>0.05$ dalam kemampuan menjawab soal-soal vocabulary-in-context questions pada baik laki-laki dan perempuan. Hasil perhitungan ini menunjukkan bahwa tidak ada perbedaan yang signifikan antara laki-laki dan perempuan dalam kemampuannya memjawab soal-soal reading comprehension berbentuk factual questions and vocabulary-in-context questions pada tes TOEFL-like.
\end{abstract}

Kata Kunci: Reading Comprehension, Factual Question, Vocabulary-In Context

Question, Gender, TOEFL 


\section{INTRODUCTION}

Reading is one of the language components which takes an essential role in teaching and learning process. As mentioned by Kusriani ${ }^{1}$ reading is important because it is not only about acquiring the written letter of one's spoken language, but it is also the procedure of creating the meaning of words, sentences, and linked paragraphs that can be called as comprehension. This is related to Susilo ${ }^{2}$ who asserts reading comprehension level explains the connection of the process to find and understand the information in the reading text. It can be assumed that reading comprehension is an activity to comprehend the content of reading until readers know the aim and the idea of the reading text.

There are major differences between males and females as readers in reading attainment in terms of gender, cognitive abilities, and cross-cultural perspectives ${ }^{3,4,5}$. It is widely accepted that females perform better in reading comprehension tests. This is in line with the report of Program for International Student Assessment (PISA) in 2009 stated that female students in Canada significantly outscored their male counterpart in reading comprehension by 23 points the report also revealed that females always perform better in reading comprehension in 57 countries around the world participating in the PISA.

Besides PISA, one of the English proficiency tests that is used to measure ability in mastering English level is the Test of English as a Foreign Language (TOEFL). Based on Educational Testing Service report ${ }^{6}$, TOEFL is the most popular and most common English proficiency test. Certified TOEFL score is used

1 Kusriani, Ika. "Using Jigsaw Technique to Improve Reading Comprehension Skill at The Eight Grade Students of SMPN 3 Mlati Yogyakarta in The Academic Year of 2012/2013." Skripsi S1. Jogja: Jurusan Pendidikan Bahasa Inggris, UNY. (2013).

2 Susilo, Sigit Vebrianto. "Cooperative Learning Make A Match Dalam Pembelajaran Reading Comprehension Di Kelas IV Sekolah Dasar.” Jurnal Cakrawala Pendas 1.1. (2015).

3 Lynn, Richard \& Jaan Mikk. (2009). "Sex differences in reading achievement". TRAMES: $A$ Journal of the Humanities and Social Sciences, 13(63/58), 1, 3-13. http://dx.doi.org/10.3176/tr.2009.1.01

4 Reilly, David. "Gender differences in reading from a cross-cultural perspective: The contribution of gender equality". International Convention of Psychological Science, Amsterdam, Netherlands. (2015). http://dx.doi.org/10.13140/RG.2.2.18218.72647

5 Reilly, David, David L. Neumann, and Glenda Andrews. "Sex and sex-role differences in specific cognitive abilities." Intelligence 54: 147-158. (2016) http://dx.doi.org/10.1016/j.intell.2015.12.004

6 Educational Testing Service. Test and score data summary for TOEFL iBT tests and TOEFL PBT tests. (April 8 $8^{\text {th } 2020) . ~ h t t p: / / w w w . e t s . o r g / t o e f l / ~}$ 
in various situations for example to enroll in a university, to study abroad, or to apply for a scholarship in order to pursue higher education ${ }^{7}$. Indeed, some universities in Indonesia including the University of Mataram have required their students to achieve the minimum TOEFL score of around 400-500 prior to their graduation. This is in line with the new policy of "Merdeka Belajar-Kampus Merdeka" issued by the Ministry of education and Culture that requires university students to improve their literacy in reading, mathematics and science. This policy has gained more and more positive responses from the students (Putera \& Sugianto, 2020) ${ }^{8}$.

Judging from the methods and the tools used in the implementation of the test, the TOEFL can be divided into three type, namely Paper-based TOEFL (PBT), Computer-based TOEFL (CBT), and Internet-based TOEFL (iBT). Meanwhile, in terms of recognition and utilization, TOEFL can be divided into three types. The first is the International TOEFL / Official TOEFL. These test scores are valid and recognized in all institutions in over the world. The second type is the Institutional TOEFL. This TOEFL score is only recognized by several institutions. This type of TOEFL is usually used as a requirement for applying for scholarships, continuing education at certain institutions, and applying for jobs. The last type is Local TOEFL (TOEFL-Prediction / TOEFL-Like). This TOEFL score is only recognized by the organizing institution, although there are other institutions that use it as a predictive score. This type of TOEFL can be held at any time and relatively low in cost.

Related to reading comprehension test, there are seven types of TOEFL reading comprehension test ${ }^{9}$. The first is the overview questions that ask learners to identify an answer choice that correctly summarizes the author's main idea, the subject of the whole passage, or the author's reason for writing the passage. The second is factual question that ask learners to locate and identify specific information and details in the passage. The third is negative questions that ask learners to identify

7 Abe, Osei, Asuka Matsuzaki, Mariko Wakita, Rie Koizumi. "Which should be dominant in Japan the TOEFL iBt or IELTS?: What does a Test Measure?.” Jutendo Medical Journal. 64 (2). 101-104. (2018). https://doi.org/10.14789/jmj.2018.64.JMJ16-WN13.

8 Putera, Lalu Jaswadi, \& Riris Sugianto. "Perception and optimism about two-semester offcampus internship program of the Kampus Merdeka-Merdeka Belajar (Freedom CampusFreedom To Learn) policy among university students". JOLLT Journal of Languages and Language Teaching. 8 (3). 264-275. (2020). https://bit.ly/3tagCqg.

9 Rogers, Bruce. The complete guide to the TOEFL test. Heinle Cengage Learning. (2011). 
which of the answer choices is not discussed in the passage. The fourth is scanning questions. These questions ask learners to find the place in the passage that some topic is mentioned. The fifth is inference questions that ask learners to draw the conclusion of the passage. The sixth type is vocabulary-in-context questions that ask learners to identify the meaning of a word or phrase as used in the passage. The last type is the reference questions that ask learners to identify the noun to which a pronoun or other expression refers to. Among those types, factual and vocabularyin-context questions are the ones with the highest percentage type of questions in the TOEFL reading comprehension test ${ }^{10}$.

In view of the importance of having good reading comprehension skill along with the variety of its question types, and bearing in mind that some studies have shown that female students are superior to males in reading comprehension, the researcher is interested to conduct a study on gender-based analysis of the students' ability in answering factual and vocabulary-in-context questions of the TOEFL-Like test to the second semester students of the English Education Program at Mataram University.

\section{LITERATURE REVIEW}

\section{Reading Comprehension}

Reading comprehension is essential for reading because readers must have the ability to understand reading material that already read before ${ }^{11}$. Comprehension is fundamentally the goal of both reading and listening ${ }^{12,13}$. Reading without comprehending it may lead to miss some information or messages. Reading cannot be disassociated from comprehension because to interpret and understand the written symbols, understand the text is a must.

10 Rogers, Bruce. The complete guide to the TOEFL test. Heinle Cengage Learning. (2011).

11 Zimmerman, Lisa. "Learning from the best: reading literacy development practices at a highperforming primary school." Per Linguam 33.2: 36-50. (2017). https://doi.org/10.5785/33-2-740.

12 Nayton, Mandy. "Factors that contribute to successful reading comprehension." DSF Bulletin (2013). https://bit.ly/31iscEl.

13 Davey, Beth. "Factors affecting the difficulty of reading comprehension items for successful and unsuccessful readers." The Journal of Experimental Education 56.2 (1988): 67-76. https://doi.org/10.1080/00220973.1988.10806468. 
Woolley $^{14}$ stated that reading comprehension is the process to get an understanding of the text. Gilakjani and Sabouri ${ }^{15}$ also argued that the purpose of reading comprehension is to understand the meaning of the text rather than the meaning of the words. Thus, reading comprehension is some activity to understand the information, basic skill to know the aim of reading material, and the way of learning words.

In reading comprehension, there are at least two people included, which are the researcher and the reader. The process of comprehending the text includes the deciphering of a researcher's words and the reader's prior knowledge to build up a proximate understanding of the researcher's messages. Using appropriate reading strategies can improve the second/foreign language performance ${ }^{16}$. Two essential elements of successful reading as concluded by Gough and Tunmer are included "the capacity to read the words on the page accurately and the capacity to understand or comprehend the message or content being read"17. To achieve this success, a variety of methods and strategies such as KWL (Know-While-Learned), Porpe (Predict, Organize, Rehearse, Practice, and Evaluate $)^{18}$, $\operatorname{comics}^{19}$, and short story ${ }^{20}$ needs to be combined and developed in teaching reading. In addition, intensive practice of 'question generation' activity together with creating answers to the generated

14 Woolley, Gary. "Reading comprehension." Reading Comprehension. Springer, Dordrecht. (2011). 1534. https://doi.org/10.1007/978-94-007-1174-7_2.

15 Gilakjani, Abbas Pourhosein, \& Narjes Banou Sabouri. "How can students improve their reading comprehension skill.” Journal of Studies in Education 6.2 (2016): 229-240. http://dx.doi.org/10.5296/jse.v6i2.9201

16 Anderson, Neil J. "Metacognitive Reading Strategies Increase L2 Performance." The Language Teacher, 27, 20-22. (2003).

17 Gough, Philip B., and William E. Tunmer. "Decoding, reading, and reading disability." Remedial and special education 7.1 (1986): 6-10.

18 Hadi, Alfan. "The Effectiveness of Porpe (Predict, Organize, Rehearse, Practice, and Evaluate) Method to Teach Reading Viewed from Students' Self-Esteem". PALAPA, Vol. 6, no. 2, Nov 2018), pp. 98-20. https://ejournal.stitpn.ac.id/index.php/palapa/article/view/69.

19 Nafisah, B. Zuhrotun, \& Aditya Pratama. "Using Comic Strips to Improve Students' Motivation and Reading Comprehension at MA Raudlatusshibyan NW Belencong". PALAPA, Vol. 8, no. 2, (Nov. 2020), pp. 404-17, https://ejournal.stitpn.ac.id/index.php/palapa/search/search.

20 Jumatriadi. "The Effectiveness of Using Short Story to Improve Students' Ability in Reading English Texts: Experimental Study at the Eight Grade Students of MTs. AL-Madani Pelulan in Academic". PALAPA, Vol. 6, no. 2, (Nov. 2018), pp. 30-48. https://ejournal.stitpn.ac.id/index.php/palapa/article/view/66. 
questions by the students themselves can be a very effective tool at improving students' reading comprehesnion ability ${ }^{21}$.

All of the theories mentioned above conclude that the ability to get the information and the meaning of the texts is called reading comprehension. Readers' prior background, experiences, and culture are the factors that influenced the process in comprehending the reading.

\section{Factual Questions}

According to Phillips, factual question is a kind of directly answered question which is stated detail question ${ }^{22}$. It asks about one piece of information rather than the passage as a whole. Pappas ${ }^{23}$ also states that factual questions known as detail questions require fact-based answers. In line with the former definitions, $\mathrm{Liu}^{24}$ hints that factual questions ask students about specific information that is stated in a part of the passage.

The answers to these questions are generally given in order in the passage, and the correct answer is often a restatement of what is given in the passage. This means that the right answer often signifies the same notion on the point of what is written in the text but the words are not precisely the same. For example, students may be asked to read a passage and then respond to a series of factual questions based on what they read. Personal feelings or views are not included in this type of question, and each answer must be backed up by evidence.

21 Thohir, Lalu, Nawawi Nawawi., Muhammad Amin, \& Lalu Jaswadi Putera. "The Effectiveness of Question-Generation Strategy on Improving the Undergraduate Students' Reading Ability”. (2020, August). In 1st Annual Conference on Education and Social Sciences (ACCESS 2019) (pp. 73-76). Atlantis Press. https://dx.doi.org/10.2991/assehr.k.200827.020.

22 Phillips, Deborah. Longman complete course for the TOEFL test: preparation for the computer and paper tests. New York: Addison-Wesley Logman. (2001).

23 Pappas, Christopher. "Factual questions in eLearning, What elearning professionals should know". Elearning Design and Development. (2015). (Retrieved: September 2020). https://elearningindustry.com/.

24 Liu, James. "10 TOEFL Reading Question Types”. (2018). (Retrieved: Sepetember 2020). https://www.bestmytest.com/. 


\section{Vocabulary-in-Context Questions}

Rogers argues that vocabulary-in-context question ask participants to identify the meaning of word and phrase as used in the passage ${ }^{25}$. He divides it into two types of question namely vocabulary questions containing difficult words and simple word $^{26}$. Vocabulary questions containing difficult word may ask participants to determine the meaning of a difficult word in a reading passage, a word that participants are not expected to know. In this case, the passage will probably give the participants a clear indication of what the word means. Meanwhile, vocabulary questions containing simple words is simple version from the difficult one, a word that participant see often in everyday English.

\section{Gender and Learning Language}

According to Nurhaeti ${ }^{27}$, gender is a difference in roles, positions, and traits attached to men and women through social and cultural construction. Fakih ${ }^{28}$ also states that the concept of gender is a trait inherent in both men and women socially and culturally constructed. The history of gender differences between men and women types has occured through a very long process. Therefore, the formation of gender difference due to many things, including being formed, socialized, strengthened, constructed socially or culturally, through the diversity and the nation. Through a long process, gender socialization is finally considered to be God's provision as if it is biological that cannot anymore be changed so that gender differences are considered and understood as both male and female nature.

Furthermore, Riyadi ${ }^{29}$ puts forward that gender is a variety of characteristics related to, and distinguishing between, masculinity and femininity. These characteristics refer to gender biologically where masculine is male and feminine is female. In sociology, gender is not only about gender, but also its social role and

25 Rogers, Bruce. The complete guide to the TOEFL test. Heinle Cengage Learning. (2011).

26 Phillips, Deborah. Longman complete course for the TOEFL test: preparation for the computer and paper tests. New York: Addison-Wesley Logman. (2001).

27 Nurhaeti. Kebijakan public pro gender cetakan pertama. Surakarta: UNS Press. (2009).

28 Fakih, M. Analisis gender \& transformasi sosial cetakan kelima belas. Yogyakarta: Pustaka Pelajar. (2013).

29 Riyadi. Pengarub buman capital dan gender terbadap kualitas auditor pada kantor akuntan publik di Indonesia. Semarang: Universitas Diponegoro. (2015). 
identity in society. Following the conceptualization of gender above, we can conclude that gender is composed of culturally constructed male identity and female identity.

There has been debate on the issue of gender in language learning. A number of researchers focused on gender-related issues, such as language learning capacity, motivation, instructor attitudes, learning styles and techniques, student engagement, instructional tools, testing, and pedagogies. Zoghi, Kazemi, and Kalani ${ }^{30}$ find that EFL learning is to some extent related to gender and it has a significant effect on the achievement test. This study indicates that however there is a significant difference between males' and females' performance, the magnitude of the difference and the strength of association between the total males and the total females is relatively small. Therefore, gender could have a small effect on students' EFL achievement tests.

Meanwhile, Akram and $\mathrm{Ghani}^{31}$ state that there are no overall statistically significant differences between male and female participants in their achievement in learning English. Moreover, the analysis of variance shows no significant differences between males and females in their parental encouragement, degree of instrumentality, English class anxiety, ethnocentrism, cultural identity, need for achievement, interest in foreign languages and motivational intensity.

\section{The Concepts of TOEFL and the TOEFL-Like}

Test of English as a Foreign Language (TOEFL) is one of the tests that is used to measure students' ability in learning English. According to Phillips, TOEFL is a test used to measure the students' level of English as a foreign language ${ }^{32}$. It means that TOEFL becomes the measurement of admission for non-native students. Similarly, Abboud and Hussein also states that TOEFL has become a standardized

30 Zoghi, Masoud, Seyyed Ali Kazemi, \& Ali Kalani. "The effect of gender on language learning." Journal of Novel Applied Sciences 2.4 (2013): 1124-1128.

31 Akram, Muhammad., \& Mamuna Ghani. "Gender and language learning motivation". Academic Research International 4(2), 536-540. (2013). https:/ / bit.ly/3coyQ2q.

32 Phillips, Deborah. Longman complete course for the TOEFL test: preparation for the computer and paper tests. New York: Addison-Wesley Logman. (2001). 
test in measuring students' English proficiency of non-native English speakers ${ }^{33}$. In Indonesia TOEFL is used as a requirement for the students to graduate, to apply for a job, to study abroad, and to get a scholarship to pursue their higher education. In line with this, Antoni explains that TOEFL is a requirement in applying for a job, staffs recruitment, and in academic purposes ${ }^{34}$.

Paper-based Test (PBT), Computer-based Test (CBT), and Internet-based Test (iBT) are three types of TOEFL. Paper-based TOEFL (PBT) is a test performed using a writing instrument (pencil 2B), a question sheet and answer sheet.Computer-based TOEFL (CBT) is test performed using a computer tool without encasing both a writing device and answer sheet. Internet-based TOEFL (iBT) is test conducted using the Internet.

Furthermore, in terms of recognition and utilization, TOEFL can be divided into three types. The first is the International TOEFL / Official TOEFL. These test scores are valid and recognized in all institutions in over the world. The second type is the Institutional TOEFL. This TOEFL score is only recognized by several institutions. This type of TOEFL is usually used as a requirement for applying for scholarships, continuing education at certain institutions, and applying for jobs. The last type is Local TOEFL (TOEFL-Prediction / TOEFL-Like). This TOEFL score is only recognized by the organizing institution, although there are other institutions that use it as a predictive score. This type of TOEFL can be held at any time and relatively low in cost. In other word TOEFL-Like is the prediction of TOEFL.

33 Abboud, Zaidoon Abdul Razaq, \& Nagham Ja'far Hussein. "The difficulties faced by advanced Iraqi foreign learners in passing ITP TOEFL test." Journal of Basrab Researches (Humanities Series) 36.4 (2011): 110-138. https://www.iasj.net/iasj/download/3b3db1f2c115622b.

34 Antoni, Rivi. “An Analysis on 6th Semester Students' Toefl Experience at English Department of Teachers Training and Education Faculty of Pasir Pengaraian University." Edu Research 3.1 (2014): 9-16. https://bit.ly/3szYAhC. 


\section{RESEARCH METHODS}

This study used quantitative descriptive method in the form of secondary data analysis taken from students' scores of the TOEFL-Like reading comprehension test. The test was administered in the TOEFL Socialization and Training Program on the $14^{\text {th }}$ of December 2019 at the University of Mataram. A total of 121 students were participated in the test. A number of twenty-one male and twenty-one female sixth semester students were selected as samples using random sampling technique. Focus of this present study was on the male and female students' scores in answering factual and vocabulary-in-context questions of the TOEFL-Like reading comprehension test. Data were analyzed using SPSS independent sample t-test that rules: if the value of the sig. 2-tailed is higher than 0.05 that means there is no significant difference between male and female students' ability in answering factual and vocabulary-in-context questions of the TOEFL-Like reading comprehension test; while if the value of the sig. 2-tailed is lower than 0.05 that means there is a significant difference between male and female students' ability in answering factual and vocabulary-in-context questions of the TOEFL-Like reading comprehension test.

\section{FINDINGS AND DISCUSSION}

\section{Findings}

After obtaining all data, the researcher used formula of independent sample ttest to find out whether or not there was a significant difference of male and female students' ability in answering factual questions of the TOEFL-Like Test using SPSS (Statistic Package Social and Science) computer program.

Table 1 shows the mean score of both male and female students in answering factual questions. The mean score of male students is 26.190 while that of the female students' is 22.619 . 
Table 1. The computation of male and female students' scores in answering factual questions of the TOEFL-Like reading comprehension test.

\begin{tabular}{|lr|l|l|l|l|}
\hline & Gender & $\mathrm{N}$ & Mean & Std. Deviation & $\begin{array}{l}\text { Std. Error } \\
\text { Mean }\end{array}$ \\
\hline $\begin{array}{l}\text { Students' score in Male } \\
\text { answering } \\
\text { questions }\end{array} \quad 21$ & 26.190 & 10.3016 & 2.2480 \\
factual Female & 21 & 22.619 & 10.2480 & 2.2363 \\
\hline
\end{tabular}

Table 2 shows that the Sig. Levene's Test for Equality of Varience is $0.896>$ 0.05, which means that the data variance between male and female groups is homogeneous or the same. So, the interpretation of the Independent Samples Test is guided by those contained in the "Equal Variances Assumed" table.

The Independent Samples Test table in the Equal Variances Assummed shows that the Sig. (2-tailed) is of $0.267>0.05$, which means that the first $\mathrm{H}_{0}$ is accepted and the first $\mathrm{H}_{\mathrm{a}}$ is rejected. It means that there is no significant difference between male and female students' ability in answering the factual question of the TOEFL-Like Reading Comprehension Test. Furthermore, from the output table below, it is known that the "Mean Difference" value is 3.5714. This value shows the difference between the average student learning outcomes in the male and female groups and the difference between these differences is -2.8372 to $9,9800(95 \%$ confidence interval of the Difference Lower Upper).

Table 2. The result of independent sample t-test of male and female students' ability in answering factual questions of the TOEFL-Like reading comprehension test.

\begin{tabular}{|c|c|c|c|c|c|c|c|c|c|}
\hline \multirow{3}{*}{$\begin{array}{l}\text { Students' score in answering } \\
\text { factual question }\end{array}$} & \multicolumn{2}{|c|}{$\begin{array}{c}\text { Levene's Test } \\
\text { for Equality of } \\
\text { Variances }\end{array}$} & \multicolumn{7}{|c|}{ t-test for Equality of Means } \\
\hline & \multirow[t]{2}{*}{$\mathrm{F}$} & \multirow[t]{2}{*}{ Sig. } & \multirow[t]{2}{*}{$\mathrm{t}$} & \multirow[t]{2}{*}{ df } & \multirow{2}{*}{$\begin{array}{l}\text { Sig. (2- } \\
\text { tailed) }\end{array}$} & \multirow{2}{*}{$\begin{array}{c}\text { Mean } \\
\text { Differe } \\
\text { nce }\end{array}$} & \multirow{2}{*}{$\begin{array}{l}\text { Std. Error } \\
\text { Difference }\end{array}$} & \multicolumn{2}{|c|}{$\begin{array}{c}95 \% \text { Confidence Interval } \\
\text { of the Difference }\end{array}$} \\
\hline & & & & & & & & Lower & Upper \\
\hline Equal variances assumed & 0.017 & 0.896 & 1.126 & 40 & 0.267 & 3.5714 & 3.1709 & \begin{tabular}{|r|}
-2.8372 \\
\end{tabular} & 9.98 \\
\hline Equal variances not assumed & & & 1.126 & 39.999 & 0.267 & 3.5714 & 3.1709 & -2.8372 & 9.98 \\
\hline
\end{tabular}


Moreover, Table 3 shows the mean score of male students in answering vocabulary-in-context question is 30.152 while the mean score of female students in answering factual question is 30.686.After obtaining all those data, then the researcher used formula of independent sample t-test in order to find out the significant difference of male and female students' ability in answering vocabulary-incontext question of the TOEFL-Like Test using SPSS (Statistic Package Social and Science).

Table 3. The computation of male and female students' score in answering vocabulary-in-context questions of the TOEFL-Like reading comprehension test.

\begin{tabular}{|r|l|l|l|l|}
\hline Gender & $N$ & Mean & Std. Deviation & $\begin{array}{l}\text { Mtd. Error } \\
\text { Mean }\end{array}$ \\
\hline $\begin{array}{l}\text { Students' score in Male } \\
\text { answering vocabulary-in- Female } \\
\text { context questions }\end{array}$ & 21 & 30.152 & 8.8903 & 1.9400 \\
\hline
\end{tabular}

As shown in Table 4, the Sig. Levene's Test for Equality of Varience is 0.571 $>0.05$, which means that the data variance between male and female groups is homogeneous. So, the interpretation of the Independent Samples Test is guided by those contained in the "Equal variences assumed" table.

The Independent Samples Test table in the Equal Variances Assummed shows that the Sig. (2-tailed) of $0.837>0.05$, so it can be concluded that the second $\mathrm{H}_{0}$ is accepted and the second $\mathrm{H}_{\mathrm{a}}$ is rejected. This means that there is no significant difference between male and female students' ability in answering the vocabulary-incontext question of the TOEFL-Like Reading Comprehension Test.

Furthermore, from the output table below, it is known that the "Mean Difference" value is -0.5333 . This value shows the difference between the average student learning outcomes in male and female groups and the difference is -5.7417 4.6750 (95\% confidence interval of the Difference Lower Upper). 
Table 4. The result of independent sample t-test of male and female students' ability in answering vocabulary-in-context questions of the TOEFL-Like reading comprehension test.

\begin{tabular}{|c|c|c|c|c|c|c|c|c|c|}
\hline \multirow{3}{*}{$\begin{array}{c}\text { Students' score in answering } \\
\text { vocabulary-in-context } \\
\text { questions }\end{array}$} & \multicolumn{2}{|c|}{$\begin{array}{c}\text { Levene's Test } \\
\text { for Equality of } \\
\text { Variances }\end{array}$} & \multicolumn{7}{|c|}{ t-test for Equality of Means } \\
\hline & \multirow[t]{2}{*}{$\mathrm{F}$} & \multirow[t]{2}{*}{ Sig. } & \multirow[t]{2}{*}{$\mathrm{t}$} & \multirow[t]{2}{*}{ df } & \multirow[t]{2}{*}{$\begin{array}{l}\text { Sig. ( } 2- \\
\text { tailed) }\end{array}$} & \multirow{2}{*}{$\begin{array}{c}\text { Mean } \\
\text { Differe } \\
\text { nce }\end{array}$} & \multirow{2}{*}{$\begin{array}{c}\text { Std. Error } \\
\text { Difference }\end{array}$} & \multicolumn{2}{|c|}{$\begin{array}{l}95 \% \text { Confidence Interval } \\
\text { of the Difference }\end{array}$} \\
\hline & & & & & & & & Lower & Upper \\
\hline Equal variances assumed & 0.327 & 0.571 & -0.207 & 40 & 0.837 & -0.533 & 2.577 & -5.7417 & 4.675 \\
\hline Equal variances not assumed & & & -0.207 & 39.3 & 0.837 & -0.533 & 2.577 & -5.7446 & 4.6779 \\
\hline
\end{tabular}

\section{DISCUSSION}

The results of the Independent sample t-test reveal that the t-value of sig. 2tailed is higher than 0.05 . This means that there is no significant difference between male and female students' ability in answering factual and vocabulary-in-context questions of the TOEFL-Like reading comprehension test. The result of this present study is in line with a research conducted by Yulisna that aimed to find out whether there was or not a significant difference in the male and female students' reading achievement ${ }^{35}$. Her study also revealed that there was no significant difference between male and female students' ability in reading comprehension. In addition to that, a study conducted by Akram \& Ghani also supports the result of this present study that there were no overall statistically significant differences between male and female participants in their achievement in learning reading (English) ${ }^{36}$.

Despite that, the results of this current research contradict with the one conducted by Zainudin found that there were major differences between male and female as readers in terms of their reading attainment ${ }^{37}$. This contradiction is likely due to the gap in the level of competence among participants in both studies: the former used college students as the samples of the study while the later used second

35 Yulisna. The reading ability of female and male students at SMPN 2 Singkep: A comperative study. Journal Academic. http://hdl.handle.net/123456789/734. (2012).

36 Akram, Muhammad., \& Mamuna Ghani. "Gender and language learning motivation". Academic Research International 4(2), 536-540. (2013). https://bit.ly/3coyQ2q.

37 Zainudin, A. (2013). Cooperative study on reading ability between male and female students at SMPN 1 Praya Timur at the second grade in academic year 2012/2013. (A Bachelor Thesis). Mataram: Universitas Mataram. 
grade students of junior high school as the samples in his study. The former's samples belong in pre-intermediate to intermediate level of competence while the later's belonged in the basic to elementary level of competence. This huge level of competence gap certainly might have invoked the inconsistent results of this current study with the previous one.

\section{CONCLUSION AND SUGGESTION}

\section{Conclusion}

Based on the findings and results of the study, the researcher concludes that there is no significant difference between male female students' ability in answering both the factual and the vocabulary-in-context questions of the TOEFL-Like reading comprehension test. It was statistically proven by the fact that the value of Sig. 2tailed in the independent sample t-test is higher than 0.05 both in the scores of answering factual questions $(0.267>0.05)$ and in the vocabulary-in-context questions $(0.837>0.05)$.

\section{Suggestion}

The researcher provides several recommendations for students, teachers, and future researchers. For the students, they should be informed that there is no significant difference between male and female in their reading comprehension ability especially in terms of answering factual and vocabulary-in-context questions. The ability to score better in reading comprehension test is not determined by the gender instead by how well he/she prepares and performs before-while-after the test. There is no such superiority or inferiority among others in terms of reading ability. Both have the same chance of getting a good result in any kind of tests not only in TOEFL as long as the conditions are met.

For the lecturers, they are suggested to give more attention to these specific type of questions in the reading comprehension test by giving more relevant practices of reading comprehension test. For future researchers who are interested in investigating similar or relevant topics, they are suggested to conduct research using different methods to get more in depth data relevant to this study. The future 
researchers should also study the determining variables such as the psychological and health conditions of the students which were overlooked in this study.

\section{REFERENCES}

Abboud, Zaidoon Abdul Razaq, \& Nagham Ja'far Hussein. “The difficulties faced by advanced Iraqi foreign learners in passing ITP TOEFL test." Journal of Basrah Researches (Humanities Series) 36.4 (2011): 110-138.

https://www.iasj.net/iasj/download/3b3db1f2c115622b.

Abe, Osei, Asuka Matsuzaki, Mariko Wakita, Rie Koizumi. "Which should be dominant in Japan the TOEFL iBt or IELTS?: What does a Test Measure?." Jutendo Medical Journal. 64 (2). 101-104. (2018).

https://doi.org/10.14789/jmj.2018.64.JMJ16-WN13.

Akram, Muhammad., \& Mamuna Ghani. "Gender and language learning motivation". Academic Research International 4(2), 536-540. (2013). https://bit.ly/3coyQ2q.

Anderson, Neil J. "Metacognitive Reading Strategies Increase L2 Performance." The Language Teacher, 27, 20-22. (2003).

Antoni, Rivi. “An Analysis on 6th Semester Students' Toefl Experience at English Department of Teachers Training and Education Faculty of Pasir Pengaraian University." Edu Research 3.1 (2014): 9-16. https://bit.ly/3szYAhC.

Davey, Beth. "Factors affecting the difficulty of reading comprehension items for successful and unsuccessful readers." The Journal of Experimental Education 56.2 (1988): 67-76. https://doi.org/10.1080/00220973.1988.10806468.

Educational Testing Service. Test and score data summary for TOEFL iBT tests and TOEFL PBT tests. (April $8^{\text {th }}$ 2020). http://www.ets.org/toefl/.

Fakih, Mansour. Analisis gender \& transformasi sosial cetakan kelima belas. Yogyakarta: Pustaka Pelajar. (2013).

Gilakjani, Abbas Pourhosein, \& Narjes Banou Sabouri. "How can students improve their reading comprehension skill." Journal of Studies in Education 6.2 (2016): 229240. http://dx.doi.org/10.5296/jse.v6i2.9201.

Gough, Philip B., and William E. Tunmer. "Decoding, reading, and reading disability." Remedial and special education 7.1 (1986): 6-10.

http://dx.doi.org/10.13140/RG.2.2.18218.72647.

Hadi, Alfan. "The Effectiveness of Porpe (Predict, Organize, Rehearse, Practice, and Evaluate) Method to Teach Reading Viewed from Students' SelfEsteem". PALAPA, Vol. 6, no. 2, (Nov 2018), pp. 98-20. https:// ejournal.stitpn.ac.id/index.php/palapa/article/view/69.

Jumatriadi. 'The Effectiveness of Using Short Story to Improve Students' Ability in Reading English Texts: Experimental Study at the Eight Grade Students of 
MTs. AL-Madani Pelulan in Academic". PALAPA, Vol. 6, no. 2, (Nov. 2018), pp. 30-48. https:// journal.stitpn.ac.id/index.php/palapa/article/view/66.

Kusriani, Ika. "Using Jigsaw Technique to Improve Reading Comprehension Skill at The Eight Grade Students of SMPN 3 Mlati Yogyakarta in The Academic Year of 2012/2013." Skripsi S1. Jogja: Jurusan Pendidikan Bahasa Inggris, UNY. (2013).

Liu, James. "10 TOEFL Reading Question Types”. (2018). (Retrieved: Sepetember 2020). https://www.bestmytest.com/.

Lynn, Richard \& Jaan Mikk. (2009). "Sex differences in reading achievement". TRAMES: A Journal of the Humanities and Social Sciences, 13(63/58), 1, 3-13. http://dx.doi.org/10.3176/tr.2009.1.01.

Nafisah, B. Zuhrotun, \& Aditya Pratama. "Using Comic Strips to Improve Students' Motivation and Reading Comprehension at MA Raudlatusshibyan NW Belencong". PALAPA, Vol. 8, No. 2, (Nov. 2020), pp. 404-17, https:// ejournal.stitpn.ac.id/index.php/palapa/search/search.

Nayton, Mandy. "Factors that contribute to successful reading comprehension." DSF Bulletin (2013). https:// bit.ly/31iscEl.

Nurhaeti. Kebijakan public pro gender cetakan pertama. Surakarta: UNS Press. (2009).

Pappas, Christopher. "Factual questions in eLearning, What elearning professionals should know". Elearning Design and Development. (2015). (Retrieved: September 2020). https://elearningindustry.com/.

Phillips, Deborah. Longman complete course for the TOEFL test: preparation for the computer and paper tests. New York: Addison-Wesley Logman. (2001).

Putera, Lalu Jaswadi, \& Riris Sugianto. "Perception and optimism about twosemester off-campus internship program of the Kampus Merdeka-Merdeka Belajar (Freedom Campus-Freedom To Learn) policy among university students", JOLLT Journal of Languages and Language Teaching, Vol. 8 no. 3 (2020), pp. 264-275. (2020). https://bit.ly/3tagCqg.

Reilly, David. "Gender differences in reading from a cross-cultural perspective: The contribution of gender equality". International Convention of Psychological Science, Amsterdam, Netherlands. (2015).

Reilly, David, David L. Neumann, and Glenda Andrews. "Sex and sex-role differences in specific cognitive abilities." Intelligence 54: 147-158. (2016) http://dx.doi.org/10.1016/j.intell.2015.12.004.

Riyadi. Pengarub buman capital dan gender terbadap kualitas auditor pada kantor akuntan publik di Indonesia. Semarang: Universitas Diponegoro. (2015).

Rogers, Bruce. The complete guide to the TOEFL test. Heinle Cengage Learning. (2011).

Susilo, Sigit Vebrianto. "Cooperative Learning Make A Match Dalam Pembelajaran Reading Comprehension Di Kelas IV Sekolah Dasar.” Jurnal Cakrawala Pendas 1.1. (2015).

Thohir, Lalu, Nawawi Nawawi., Muhammad Amin, \& Lalu Jaswadi Putera. "The Effectiveness of Question-Generation Strategy on Improving the Undergraduate Students' Reading Ability". (2020, August). In 1st Annual 
Conference on Education and Social Sciences (ACCESS 2019) (pp. 73-76). Atlantis Press. https://dx.doi.org/10.2991/assehr.k.200827.020

Woolley, Gary. "Reading comprehension." Reading Comprehension. Springer, Dordrecht. (2011). 15-34. https://doi.org/10.1007/978-94-007-1174-7_2.

Yulisna. The reading ability of female and male students at SMPN 2 Singkep: A comperative study. Journal Academic. http://hdl.handle.net/123456789/734. (2012).

Zainudin, A. (2013). Cooperative study on reading ability between male and female students at SMPN 1 Praya Timur at the second grade in academic year 2012/2013. (A Bachelor Thesis). Mataram: Universitas Mataram.

Zimmerman, Lisa. "Learning from the best: reading literacy development practices at a high-performing primary school." Per Linguam 33.2: 36-50. (2017). https://doi.org/10.5785/33-2-740.

Zoghi, Masoud, Seyyed Ali Kazemi, \& Ali Kalani. "The effect of gender on language learning." Journal of Novel Applied Sciences 2.4 (2013): 1124-1128. 